\title{
A Predictive Model for Spotted Wilt Epidemics in Peanut Based on Local Weather Conditions and the Tomato spotted wilt virus Risk Index
}

\author{
R. O. Olatinwo, J. O. Paz, S. L. Brown, R. C. Kemerait, Jr., A. K. Culbreath, J. P. Beasley, Jr., and G. Hoogenboom
}

First, second, and seventh authors: Department of Biological and Agricultural Engineering, University of Georgia, Griffin 30223; third author: Department of Entomology, University of Georgia, Tifton 31793; fourth and fifth authors: Department of Plant Pathology, University of Georgia, Tifton 31793; and sixth author: Department of Crop and Soil Sciences, University of Georgia, Tifton 31793. Accepted for publication 4 June 2008.

\begin{abstract}
Olatinwo, R. O., Paz, J. O., Brown, S. L., Kemerait, R. C., Jr., Culbreath, A. K., Beasley, J. P., Jr., and Hoogenboom, G. 2008. A predictive model for spotted wilt epidemics in peanut based on local weather conditions and the Tomato spotted wilt virus risk. Phytopathology 98:1066-1074.

Tomato spotted wilt virus (TSWV), a member of the genus Tospovirus (family Bunyaviridae), is an important plant virus that causes severe damage to peanut (Arachis hypogaea) in the southeastern United States. Disease severity has been extremely variable in individual fields in Georgia, due to several factors including variability in weather patterns. A TSWV risk index has been developed by the University of Georgia to aid peanut growers with the assessment and avoidance of high risk situations. This study was conducted to examine the relationship between weather

ing seasons, and derived weather variables during the same years were analyzed using nonlinear and multiple regression analyses. Meteorological data were obtained from the Georgia Automated Environmental Monitoring Network. The best model explained $61 \%$ of the variation in spotted wilt severity (square root transformed) as a function of the interactions between the TSWV risk index, the average daily temperature in April $(\operatorname{Tav} A)$, the average daily minimum temperature between March and April (TminMA), the accumulated rainfall in March (RainfallM), the accumulated rainfall in April (RainfallA), the number of rain days in April (RainDayA), evapotranspiration in April (EVTA), and the number of days from 1 January to the planting date (JulianDay). Integrating this weatherbased model with the TSWV risk index may help peanut growers more effectively manage tomato spotted wilt disease.
\end{abstract} parameters and spotted wilt severity in peanut, and to develop a predictive model that integrates localized weather information into the risk index. On-farm survey data collected during 1999, 2002, 2004, and 2005 grow-
Additional keywords: decision support system, environmental factors, integrated pest management, pests, thrips.
Tomato spotted wilt virus (TSWV), a member of the genus Tospovirus (family Bunyaviridae) is an important plant virus that causes severe damage to peanut (Arachis hypogaea L.) in the southeastern United States. The virus causes a wide range of symptoms in peanuts and other crops. In peanuts, symptoms usually include stunting of the plant, chlorosis on leaflets, reddish discoloration, and cracking of the seed coats $(16,17,26)$. Disease development early in the season typically results in greater reduction in yield in comparison with disease development later in the season.

Tomato spotted wilt was first observed in 1986 in the peanut production regions of the southeastern United States (24). However, it was not considered a problem until it became endemic in the early 1990s (12). Severe yield losses associated with TSWV has been reported in crops including pepper, peanut, and tobacco, with total losses estimated at $\$ 100$ million in $1996(2,38)$. A sharp increase in TSWV incidence has been observed in Alabama, particularly in the southeastern-most counties (25). In North Carolina, TSWV was first detected in tobacco and tomato in 1988, although infections occurred at very low levels. By 2000, incidences of spotted wilt ranging from 25 to $50 \%$ were reported in tomato, tobacco, and pepper fields in North Carolina (22). In 2005 , losses to spotted wilt in Georgia peanut were estimated at approximately $\$ 31.7$ million (30).

Corresponding author: R. O. Olatinwo; E-mail address: olatinwo@uga.edu

doi:10.1094/PHYTO-98-10-1066

(c) 2008 The American Phytopathological Society
In 1996, a TSWV risk assessment was initiated in Georgia for peanut (6) to address the losses associated with spotted wilt and to help peanut growers assess risk levels associated with specific combinations of production practices in order to avoid high-risk situations. To obtain a risk index value for a particular field, point values were assigned to critical components of peanut production practices according to their relative influence on spotted wilt severity. When combinations of these factors are considered, an individual peanut field's risk of losses due to TSWV can be estimated $(4,6)$.

Some factors are more important than others, but no single factor can be manipulated to control the disease (15). Optimum planting dates vary slightly from year to year, but in general, avoiding early and late planting reduces the incidence and severity of spotted wilt in Georgia. However, the mechanism behind the plant's response to planting date and spotted wilt severity is not fully understood, but midseason planting dates tend to avoid the peaks of local thrips populations (43).

TSWV is transmitted by multiple species of thrips (34). Spotted wilt epidemics in Florida and Georgia can be largely attributed to western flower thrips, Frankliniella occidentalis; tobacco thrips, F. fusca; and F. bispinosa $(41,43,47,49)$. Most spotted wilt incidence in peanut is thought to be the result of primary transmission, but some secondary transmission probably occurs as well (9); this is mostly by $F$. fusca, which readily reproduces on peanut (43). A study on early transplanted tomato crops found a significant association between early population densities of adult F. occidentalis and final TSWV incidence (1).

Incidence and severity of tomato spotted wilt have been extremely variable in peanut fields in Georgia (5). Weather condi- 
tions prior and during the growing season are critical for population dynamics of the thrips vector, and perhaps transmission of spotted wilt virus. Temperature is one of the major factors that determine development of thrips (23), although temperature affects the reproduction parameters differently among different populations of $F$. occidentalis $(23,46)$. A study by Rhainds et al. (39) showed that high temperature led to an initial rapid increase in $F$. occidentalis density followed by abrupt decline in abundance. In tobacco thrips, the lower developmental threshold is estimated at $10.5^{\circ} \mathrm{C}(31)$, usually lower than the average winter temperature in South Georgia, indicating the potential for year round reproduction on alternative hosts $(12,13)$. According to Wells et al. (49), fluctuations in the dynamics of tobacco thrips populations and the proportions of viruliferous thrips in the population are apparent from April to May, when many crops in South Georgia are in the field. Environmental factors, especially rainfall and temperature, are thought to have an influence on these fluctuations.

The effect of weather factors on the severity of spotted wilt in peanuts is of significant interest to researchers and peanut growers in the southeast. Therefore, integrating a weather-based model with the current risk index might enhance its accuracy in forecasting and managing spotted wilt. The objectives of this study were (i) to examine the relationships between weather parameters and the severity of tomato spotted wilt of peanut, and (ii) to develop a predictive model that integrates localized weather information into the existing TSWV risk index.

\section{MATERIALS AND METHODS}

The study was based on on-farm surveys conducted by scientists at the University of Georgia, primarily for the development and validation of TSWV risk index for peanut grown under a wide array of production practices (4). Brown et al. (4) described how the index was developed and modified over the years, and presented some results of the on-farm surveys that were used to validate the index for peanut grown for a wide range of production practices. This study focused on 4-year survey data for the 1999, 2002, 2004, and 2005 growing seasons and percent spotted wilt severity obtained from $86,60,28$, and 69 peanut fields, respectively (Table 1). Thus, a total of 243 fields were surveyed and the average percent of spotted wilt severity (\%) from four randomly selected samples was recorded at each field according to visual assessment of spotted wilt severity (4).

Additional information about the 4-year survey is presented in Table 1 and includes the year the survey was conducted, the county surveyed, varieties cultivated, and the total number of fields surveyed. The tomato spotted wilt severity that was recorded ranged from 1 to $91 \%, 1$ to $88 \%, 3$ to $63 \%$, and 1 to $90 \%$ during the surveys in 1999, 2002, 2004, and 2005, respectively. The peanut fields that were included in the survey varied by growing season and county due to the availability of peanut fields and variability in cultural practices (e.g., crop rotation) employed by different growers.

Currently, the TSWV risk index for peanut $(7,8)$ has seven components. These components include variety, planting date, plant population, insecticide application, row pattern, tillage method, and herbicide application. From what is known about the individual risk components through field observations and experiments, a comprehensive but simple combined estimate of TSWV risk for a given field is obtained. The risk index assigns a relative importance to each component, so that an overall level of risk can be estimated. The risk index values used in this study were based on the University of Georgia 2005 point system (Table 2 ). All components, with the exception of herbicide, were included in the data analysis and model development process. Herbicide data became a component during the later years of the program, and hence were not available in all 4 years included in this study.

Meteorological data. Meteorological data were obtained from the Georgia Automated Environmental Monitoring Network, based on field locations and the nearest weather station. The network $(28,29)$ is comprised of over 75 weather stations, and each station monitors several weather parameters, including air temperature, precipitation, relative humidity, solar radiation, wind speed and direction, soil moisture, and soil temperature.

In this study, the period between 1 January and 31 May was chosen as critical for thrips development and important for successful transmission of spotted wilt, as highlighted by the significance of this period on viruliferous thrips life cycle and population dynamics, biology of TSWV, and peanut phenology in previous studies $(22,23,32,36,43,45)$. Studies on peanut planting date have shown that the peak populations of the adult thrips vector were greater for peanut planted in April or June than for peanut planted in May $(36,45)$. The most susceptible periods to TSWV infection for peanut appear to occur within the 2- to 4-week period after planting (32). This information was used in selecting months between winter and spring and the corresponding environmental variables for this study. The environmental variables derived from weather parameters during this period are presented in Table 3 along with the risk index components.

In general, the planting date of peanut is determined by various weather factors, especially rainfall and soil temperature. Derived weather variables used in this study including accumulated degree day (DD), the total amount of rainfall, the number of rain days, air temperature, evapotranspiration, water balance, and chilling hours are often based on rainfall and temperature. For each survey location, the accumulated degree day temperature, average daily temperature, accumulated rainfall, evapotranspiration, chilling hours, and water balance were calculated using the period between 1 January to 30 April, 1 January to planting date, 1 January to end of bloom, 1 March to planting date, 1 March to end of

TABLE 1 . Summary of the Tomato spotted wilt virus severity survey

\begin{tabular}{|c|c|c|c|c|}
\hline Year & County surveyed $^{\mathrm{a}}$ & Peanut variety & Planting date range & No. of fields \\
\hline 1999 & $\begin{array}{l}\text { Baker, Barrien, Brooks, Bulloch, Burke,Colquitt, Dooly, } \\
\text { Emanuel, Evans, Grady, Irwin, Laurens, Marion, } \\
\text { Miller, Randolph, Screven, Seminole, Sumter, } \\
\text { Tattnall, Toombs }\end{array}$ & $\begin{array}{l}\text { AT120, C-99R, Georgia Green, GK-7-HiOL, Florida } \\
\text { MDR-98, Southern Runner, Virugard }\end{array}$ & 14 April to 6 June & 86 \\
\hline 2002 & $\begin{array}{l}\text { Bulloch, Burke, Candler, Colquitt, Crisp, Decatur, Early, } \\
\text { Jefferson, Jenkins, Laurens, Macon, Mitchell, } \\
\text { Randolph, Seminole, Taylor, Terrell, Turner }\end{array}$ & $\begin{array}{l}\text { AT201, C-99R, Carver, Georgia Green, Anorden, } \\
\text { Virugard }\end{array}$ & 8 April to 31 May & 60 \\
\hline 2004 & $\begin{array}{l}\text { Appling, Bulloch, Burke, Dodge, Evans, Irwin, Mitchell, } \\
\text { Wilcox }\end{array}$ & $\begin{array}{l}\text { C-99R, Carver, Georgia-01R, Georgia-02C, } \\
\text { Georgia-03L, Georgia Green }\end{array}$ & 6 May to 10 June & 28 \\
\hline 2005 & $\begin{array}{l}\text { Appling, Ben Hill, Candler, Coffee, Cook, Early, Grady, } \\
\text { Miller, Pulaski, Seminole, Sumter, Terrell, Tift, } \\
\text { Toombs }\end{array}$ & $\begin{array}{l}\text { AP-3, C-99R, Carver, Georgia-01R, Georgia-02C, } \\
\text { Georgia-03L, Georgia Green, Gregory }\end{array}$ & 19 April to 20 June & 69 \\
\hline
\end{tabular}

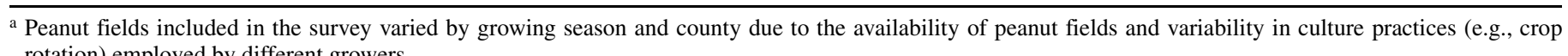
rotation) employed by different growers. 
bloom, 1 to 31 March, 1 to 30 April, and 1 March to 30 April. A comprehensive list and description of derived weather variables with the period used for the calculation is presented in Table 3 . All variables were included at the initial stage of data analysis.

Statistical analysis. The analysis was initiated with a total of 40 variables including six TSWV risk index components and the derived weather variables (Table 3). A square root data transformation was applied to the dependent variable, i.e., percent spotted wilt severity, to achieve a normal data distribution. Regression analysis procedures were performed using Statistical Analysis System (SAS) software (42) with the Akaike information criterion (AIC) and Mallow's $C p$ statistics options in PROC REG in SAS. These options were used to identify and select a subset that included the most important predictors of spotted wilt severity (dependent variable). A subset with a total of 18 variables was selected from the initial SAS analysis based on AIC and Mallow's $C p$ statistics options in SAS (Table 4).

The Akaike information criterion (1) methodology rewards goodness of fit, yet discourages over-fitting. The option was applied to obtain a subset of independent variables that best explains the data. The AIC also compares (generalized) linear models with different explanatory variables by taking the loglikelihood of the model and penalizing this according to the number of parameters estimated (48). In general, AIC is

$$
\mathrm{AIC}=2 k-2 \ln (L)
$$

where $k$ is the number of parameters, and $L$ is the likelihood function. Assuming that the model errors are normally distributed, where $n$ is the number of observations and RSS is the residual sum of squares, then AIC becomes

$$
\mathrm{AIC}=2 k+n \ln (R S S / n)
$$

Mallow's $C p$ statistic is normally used as the criterion for choosing the best subset of predictor effects when a best subset regression analysis is being performed. The option was used to find the best subset that includes only the important predictors of the respective dependent variable. Mallow's $C p$ statistic (equation 3 ) is calculated when performing variable selection

TABLE 2. The 2005 Tomato spotted wilt virus risk index for peanut

\begin{tabular}{llr}
\hline Components & \multicolumn{1}{c}{ Categories within component } & Points \\
\hline Variety & Florunner, SunOleic 97R, Flavorunner 458 & 50 \\
& Perry & 40 \\
& NC-V11, NC12C & 35 \\
& AT-201 & 30 \\
& Georgia Green, Southern Runner, Virugard, & 25 \\
& Gregory & \\
& Anorden, Andru II & 20 \\
& C-99R, Hull, Carver, GA03L & 15 \\
Planting date & GA02C, GA01R, DP1, AP3, Tifrunner & 10 \\
& Before May 1 & 30 \\
& May 1 to May 10 & 15 \\
& May 11 to May 25 & 5 \\
Plant population & May 26 to June 5 & 10 \\
& After June 5 & 15 \\
& Less than 3 plants per foot & 25 \\
At plant insecticide & 15 \\
& 3 to 4 plants per foot & 5 \\
& Nore than 4 plants per foot & 15 \\
Row pattern & Temik 15G & 15 \\
& Thimet 20G, Phorate 20G & 5 \\
Tillage & Single rows & 15 \\
Classic herbicide & Twin rows & 5 \\
& Conventional & 15 \\
& Reduced & 5 \\
& Applied & 5 \\
& Not applied & 0 \\
\hline
\end{tabular}

$$
C_{p}=\left[M S E_{P} / M S E_{K}\right][n-p-1]-[n-2(p+1)]
$$

where $M S E_{p}$ is the mean squared error with $p$ independent variables in the model, $M S E_{k}$ is the mean squared error with all independent variables in the pool, and $n$ is the number of data points. The optimal model was defined as a model having a $C p$ value close to $p+1$. A $C p$ value greater than $(p+1)$ indicates that the regression model is overspecified, which means it contains too many independent variables and there is a good chance of having multicollinearity problems. A $C p$ value less than $(p+1)$ indicates that the regression model is underspecified, indicating the probability that at least one important independent variable has been left out of the model (Table 5).

Further variable selection and fitting procedures were applied to the independent variables using a combination of "all subsets procedure" and "stepwise selection procedure" in DataFit 8.2, a curve fitting, statistical analysis, and data plotting software (Oak-

\begin{tabular}{|c|c|}
\hline Variable & Description \\
\hline Vty & Variety index value \\
\hline PD & Planting index value \\
\hline Pop & Plant population index value \\
\hline Ins & Insecticide applications index value \\
\hline Row & Row pattern index value \\
\hline Till & Tillage pattern Index value \\
\hline JulianDay & Number of days from 1 January to planting \\
\hline DD56-84JA & $\begin{array}{l}\text { Degree day accumulations from } 1 \text { January to } 30 \text { April } \\
\left(13.3 \text { to } 28.9^{\circ} \mathrm{C}\right)\end{array}$ \\
\hline DD56-84Jan-Pltdate & $\begin{array}{l}\text { Degree day accumulations from } 1 \text { January to planting } \\
\left(13.3 \text { to } 28.9^{\circ} \mathrm{C}\right)\end{array}$ \\
\hline PltD-BlmEndRainfall & $\begin{array}{l}\text { Accumulated rainfall from planting until end of } \\
\text { bloom (inch) }\end{array}$ \\
\hline PltD-BlmEndEVT & Evapotranspiration from planting until end of bloom \\
\hline PltD-BlmEndWB & Water balance from planting until end of bloom \\
\hline Jan-BlmEndRainfall & $\begin{array}{l}\text { Accumulated rainfall from } 1 \text { January until end of } \\
\text { bloom (inch) }\end{array}$ \\
\hline Jan-BlmEndEVT & Evapotranspiration from 1 January until end of bloom \\
\hline Jan-BlmEndWB & Water balance from 1 January until end of bloom \\
\hline TmaxMar-BlmEnd & $\begin{array}{l}\text { Ave. max. daily temperature from } 1 \text { March until end } \\
\text { of bloom }\left({ }^{\circ} \mathrm{C}\right)\end{array}$ \\
\hline TminMar-BlmEnd & $\begin{array}{l}\text { Ave. min. daily temperature from } 1 \text { March until end } \\
\text { of bloom }\left({ }^{\circ} \mathrm{C}\right)\end{array}$ \\
\hline TavMar-BlmEnd & $\begin{array}{l}\text { Ave. daily temperature from } 1 \text { March until end of } \\
\text { bloom }\left({ }^{\circ} \mathrm{C}\right)\end{array}$ \\
\hline TmaxMar-PD & $\begin{array}{l}\text { Ave. max. daily temperature from } 1 \text { March to } \\
\text { planting }\left({ }^{\circ} \mathrm{C}\right)\end{array}$ \\
\hline TminMar-PD & $\begin{array}{l}\text { Ave. min. daily temperature from } 1 \text { March to } \\
\text { planting }\left({ }^{\circ} \mathrm{C}\right)\end{array}$ \\
\hline TavMar-PD & Ave. daily temperature from $1 \mathrm{March}$ to planting $\left({ }^{\circ} \mathrm{C}\right)$ \\
\hline TmaxM & Ave. max. daily temperature in $\operatorname{March}\left({ }^{\circ} \mathrm{C}\right)$ \\
\hline TminM & Ave. min. daily temperature in $\operatorname{March}\left({ }^{\circ} \mathrm{C}\right)$ \\
\hline TavM & Ave. daily temperature in $\operatorname{March}\left({ }^{\circ} \mathrm{C}\right)$ \\
\hline TmaxA & Ave. max. daily temperature in April $\left({ }^{\circ} \mathrm{C}\right)$ \\
\hline $\operatorname{Tmin} \mathrm{A}$ & Ave. min. daily temperature in April $\left({ }^{\circ} \mathrm{C}\right)$ \\
\hline TavA & Ave. daily temperature in April $\left({ }^{\circ} \mathrm{C}\right)$ \\
\hline TmaxMA & $\begin{array}{l}\text { Ave. max. daily temperature in } 1 \text { March to } 30 \text { April } \\
\left({ }^{\circ} \mathrm{C}\right)\end{array}$ \\
\hline TminMA & $\begin{array}{l}\text { Ave. min. daily temperature in } 1 \text { March to } 30 \text { April } \\
\left({ }^{\circ} \mathrm{C}\right)\end{array}$ \\
\hline TavMA & Ave. daily temperature in $1 \mathrm{March}$ to $30 \mathrm{April}\left({ }^{\circ} \mathrm{C}\right)$ \\
\hline RainfallM & Accumulated rainfall in March (inch) \\
\hline RainDayM & Number of rain day in March \\
\hline RainfallA & Accumulated rainfall in April (inch) \\
\hline RainDayA & Number of rain day in April \\
\hline RainfallMA & Accumulated rainfall in 1 March to 30 April (inch) \\
\hline RainDayMA & Number of rain day in 1 March to 30 April \\
\hline Jan-PD-Rainfall & $\begin{array}{l}\text { Accumulated rainfall from } 1 \text { January to planting } \\
\text { (inch) }\end{array}$ \\
\hline EVTA & Evapotranspiration in April (inch) \\
\hline WBA & Water balance in April (inch) \\
\hline ChillHrA & Number of chilling hours in April (base $=7.2^{\circ} \mathrm{C}$ ) \\
\hline
\end{tabular}

TABLE 3. Description of risk index components and the weather variables included in the initial analysis 
dale Engineering, Oakdale, PA). The "all subsets procedure" is an exhaustive procedure for examining every possible combination of independent variables either included or excluded from the model. The computations return the "best" model for each possible number of independent variables, using model selection criteria based on the coefficient of multiple determination $\left(R^{2}\right)$, the residual sum of squares, or the standard error.

Two-way interactions between individual derived weather variable and TSWV risk index total were examined as predictor of spotted wilt severity based on nonlinear regression analysis (three-dimensional model) fitting procedure in DataFit 8.2. The coefficient of multiple determination $\left(R^{2}\right)$, the overall $F$ statistic, and $t$ test of estimated parameters significant at $P \leq 0.05$ were used for model selection.

The "stepwise selection procedure" performed in DataFit 8.2 begins with a forward step (with no variables in the model). After the forward step, the $P$ values of the variable coefficients are reexamined and any new insignificant variables are removed in a backward step. This process continues until no variables are either added or removed from the model. Squares and cross-products of the 18 variables were included in the stepwise regression procedure.

The computed variance analysis and the overall $F$ statistic were used to determine the significance of each model at $P \leq 0.05$. In the stepwise selection procedure, a $t$ test of estimated parameters with significance set at $P \leq 0.05$ was utilized to retain significant variables or drop insignificant variables. The coefficient of multiple determination $\left(R^{2}\right)$ and residual scatter plots were also used for model comparison and selection.

TABLE 4. Selected variables used in model development for predicting Tomato spotted wilt virus severity after initial analysis

\begin{tabular}{lll}
\hline Code & Variable & \multicolumn{1}{c}{ Description } \\
\hline X1 & Vty & Variety index value \\
X2 & PD & Planting index value \\
X3 & Pop & Plant population index value \\
X4 & Ins & Insecticide applications index value \\
X5 & Row & Row pattern index value \\
X6 & Till & Tillage pattern index value \\
X7 & JulianDay & Number of days from 1 January to planting \\
X8 & TavA & Ave. daily temperature in April $\left({ }^{\circ} \mathrm{C}\right)$ \\
X9 & TmaxMA & Ave. max. daily temperature in March to April $\left({ }^{\circ} \mathrm{C}\right)$ \\
X10 & TminMA & Ave. min. daily temperature in March to April $\left({ }^{\circ} \mathrm{C}\right)$ \\
X11 & TavMA & Ave. daily temperature in March to April $\left({ }^{\circ} \mathrm{C}\right)$ \\
X12 & RainfallM & Accumulated rainfall in March (inch) \\
X13 & RainDayM & Number of rain day in March \\
X14 & RainfallA & Accumulated rainfall in April (inch) \\
X15 & RainDayA & Number of rain day in April \\
X16 & ChillHrA & Number of chilling hours in April $\left(\right.$ base $\left.=7.2^{\circ} \mathrm{C}\right)$ \\
X17 & EVTA & Evapotranspiration in April (inch) \\
X18 & WBA & Water balance in April (inch) \\
\hline
\end{tabular}

The spotted wilt risk level was considered to be (i) low, if the percent severity was less than $20 \%$, (ii) moderate, if the percent severity was greater or equal to $20 \%$ but less than $40 \%$, and (iii) high, if the percent severity was greater or equal to $40 \%$. The accuracy of the selected model in predicting the risk level was evaluated based on the three-category risk levels. The frequency of the exact match between the predicted and the actual risk level was analyzed, and the percent accuracy was calculated according to the total number of observations for each year. The Bowker's test of symmetry ( $P$ value) in SAS was used to test the degree of disagreement.

\section{RESULTS}

The survey data from the four growing seasons suggested a number of weather factors that contribute to spotted wilt development in peanut. A combination of the derived weather variables (TavA, TminMA, RainfallM, and WBA), the JulianDay and the six risk index components, significantly improved the $R^{2}$ value from 0.23 to 0.54 when compared with the six risk index components alone (Table 5). The subset $(p=11)$ had a $C p$ value closer to the variable count $(p)$ as indicated in Table 5 suggesting lesser bias in the regression model. The closer the $C p$ value to the variable count $(p)$, the lesser the bias in the regression model. The variable $\operatorname{TavA}$ (average daily air temperature in April) was consistently present in all subsets. A nonlinear regression model fitting procedure performed in DataFit 8.2 showed a significant interaction between the TSWV risk index total (sum of the six components; X1 to X6) and TavA in predicting spotted wilt severity. The best nonlinear regression equation between the variables was

$$
\begin{gathered}
y=25.79 \times x-0.56 \times x^{2}+0.0053 \times x^{3}-0.00002 \times x^{4}+10763.97 \times \\
t-823.61 \times t^{2}+27.82 \times t^{3}-0.35 \times t^{4}-52806.17
\end{gathered}
$$

where $y=$ percent spotted wilt severity, $x=$ TSWV risk index total (X1 to X6), and $t=$ average daily air temperature in April $(X 8-\operatorname{TavA})$.

The values in equation 4 are the estimates of the regression coefficient and the intercept determined by nonlinear regression. The overall $F$ statistics and the $t$ test of estimated parameters were significant at $P \leq 0.05$. The proportion of variance explained by equation 4 for spotted wilt severity was approximately $42.0 \%$. The temperatures in April ranging from 19 to $22^{\circ} \mathrm{C}$ had the lowest levels of spotted wilt severity, whereas higher levels occurred with higher $\left(22\right.$ to $\left.23^{\circ} \mathrm{C}\right)$ and lower $\left(17\right.$ to $\left.18^{\circ} \mathrm{C}\right)$ temperatures based on the four growing seasons included in the survey analysis (Fig. 1).

A significant interaction $(P \leq 0.05)$ was also observed between the TSWV risk index total and the accumulated rainfall in April

TABLE 5. The "all subsets selection" models from square root (Tomato spotted wilt virus severity), risk index components, and selected environmental variables

\begin{tabular}{lccc}
\hline Variables $^{\mathrm{a}}$ & $p^{\mathrm{b}}$ & $R^{2}$ & StdErr $^{\mathrm{c}}$ \\
\hline X1 X2 X3 X4 X5 X6 & 6 & 0.23 & 1.92 \\
X1 X2 X3 X4 X5 X6 X8 & 7 & 0.33 & 1.80 \\
X1 X2 X3 X4 X5 X6 X8 X10 & 8 & 0.42 & 1.68 \\
X1 X2 X3 X4 X5 X6 X7 X8 X10 & 9 & 0.45 & 1.64 \\
X1 X2 X3 X4 X5 X6 X8 X10 X12 X18 & 10 & 1.57 & 61 \\
X1 X2 X3 X4 X5 X6 X7 X8 X10 X12 X18 & 11 & 1.51 \\
X1 X2 X3 X4 X5 X6 X7 X8 X10 X12 X14 X17 & 12 & 0.54 & 25 \\
X1 X2 X3 X4 X5 X6 X7 X8 X10 X12 X14 X16 X17 & 13 & 0.54 & 9 \\
X1 X2 X3 X4 X5 X6 X7 X8 X10 X12 X14 X15 X17 X18 & 14 & 0.54 & 1.51 \\
X1 X2 X3 X4 X5 X6 X7 X8 X9 X11 X12 X13 X14 X15 X17 & 15 & 0.54 & 1.51 \\
\hline
\end{tabular}

a X1-Vty, X2-PD, X3-Pop, X4-Ins, X5-Row, X6-Till, X7-JulianDay, X8-TavA, X9-TmaxMA, X10-TminMA, X11-TavMA, X12-RainfallM, X13-RainDayM, X14-RainfallA, X15-RainDayA, X16-ChillHrA, X17-EVTA, and X18-WBA.

b Subset variable count $(p)$.

c Standard error.

d Mallow's $C p$ value. 
(RainfallA). The best nonlinear regression equation between the variables was

$$
y=0.67 \times x-(211.03 / r)+\left(348.56 / r^{2}\right)-\left(230.29 / r^{3}\right)+
$$$$
\left(61.34 / r^{4}\right)-\left(5.52 / r^{5}\right)+11.32
$$

where $y=$ percent spotted wilt severity, $x=$ TSWV risk index total (X1 to X6), and $r=$ accumulated rainfall in April (X12RainfallA).

The values in equation 5 are the estimates of the regression coefficient and the intercept determined by nonlinear regression. The proportion of variance explained by equation 5 for spotted wilt severity was approximately $36.0 \%$. The spotted wilt severity increased with increasing accumulated rainfall above 6 inches in April (Fig. 2).

Further analysis of the squares and cross-products of the 18 variables (Table 4) in a stepwise regression procedure showed that the average daily temperature in April $(\operatorname{Tav} A)$, the average daily minimum temperature between March and April (TminMA), the accumulated rainfall in March (RainfallM), the accumulated rainfall in April (RainfallA), the number of rain days in April (X15-RainDayA), total evapotranspiration in April (EVTA), and Julian day from 1 January to planting date (JulianDay) had significant interactions with the risk index components in producing

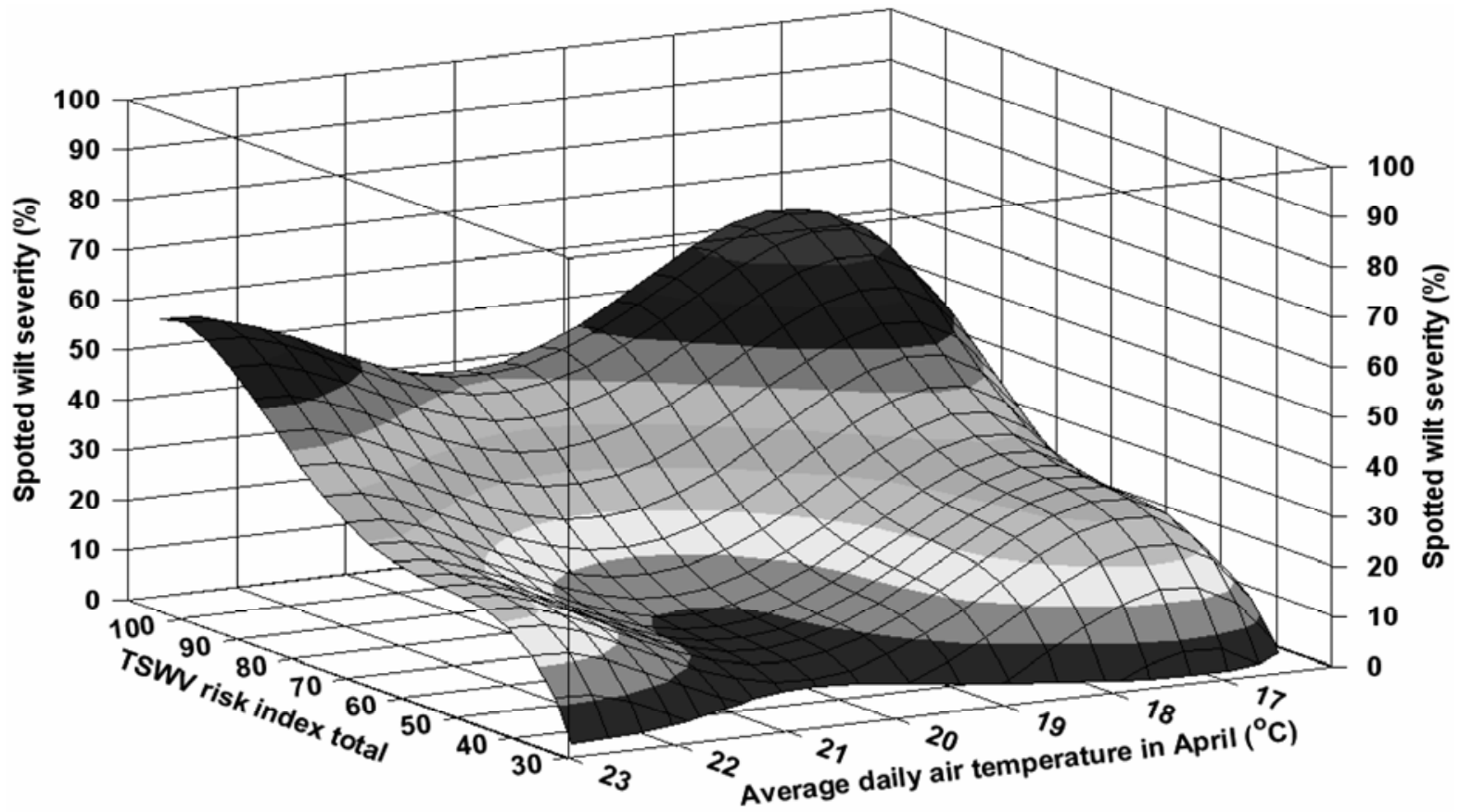

Fig. 1. Nonlinear regression model showing the interactions between Tomato spotted wilt virus (TSWV) risk index and the average daily air temperature in April $(X 8-\operatorname{Tav} A)$ in predicting the spotted wilt severity of peanut. The model explained $42 \%$ of the variation in spotted wilt severity. Coefficient of multiple determination $\left(R^{2}\right)$ was 0.42 .

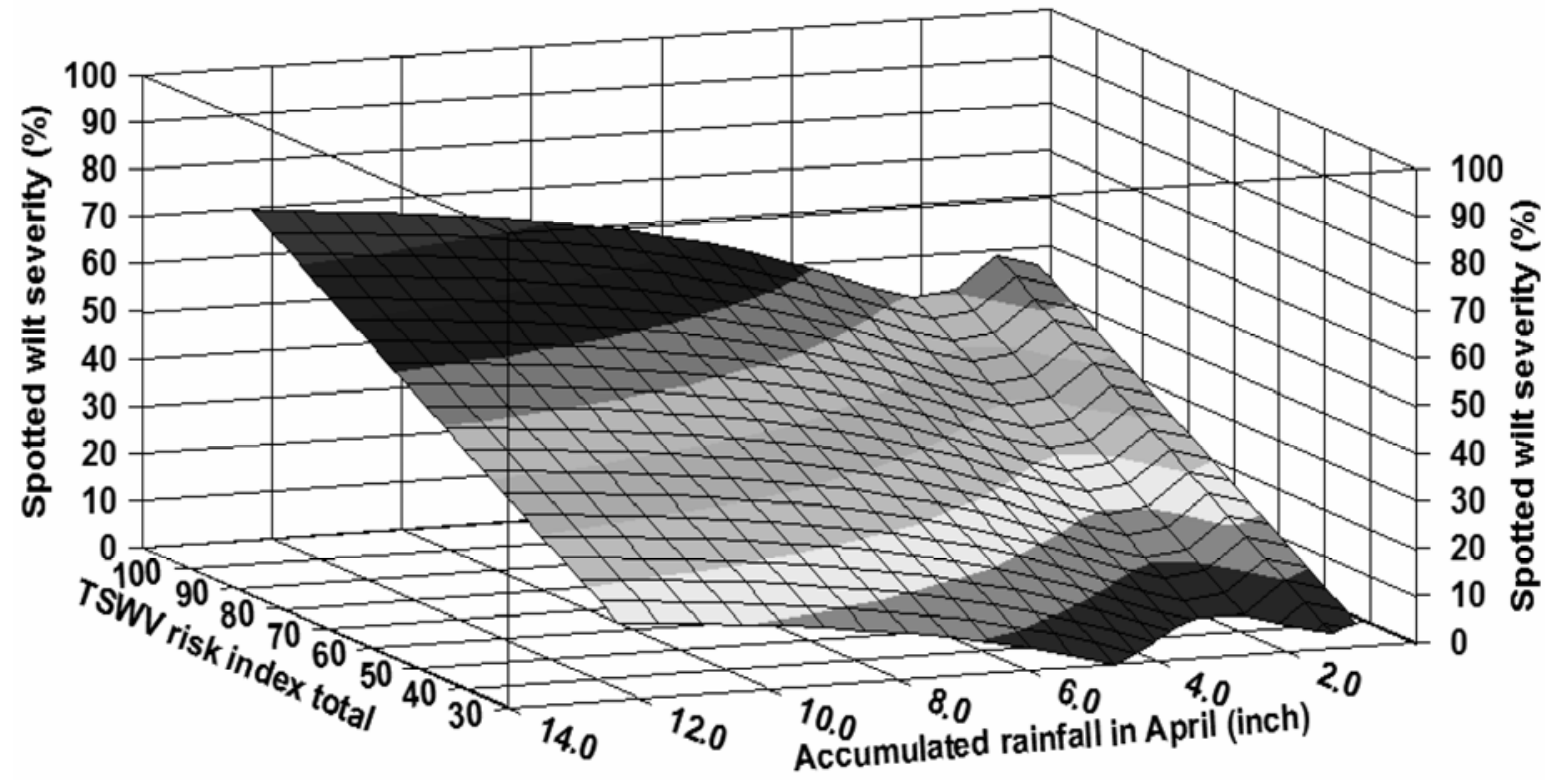

Fig. 2. Nonlinear regression model showing the interactions between Tomato spotted wilt virus (TSWV) risk index and accumulated rainfall in April ( $x 14$ RainfallA) in predicting the spotted wilt severity of peanut. The model explained $36 \%$ of the variation in spotted wilt severity. Coefficient of multiple determination $\left(R^{2}\right)$ was 0.36 . 
the best fit (equation 6) for predicting spotted wilt severity. The best overall equation from the squares and the cross-products was

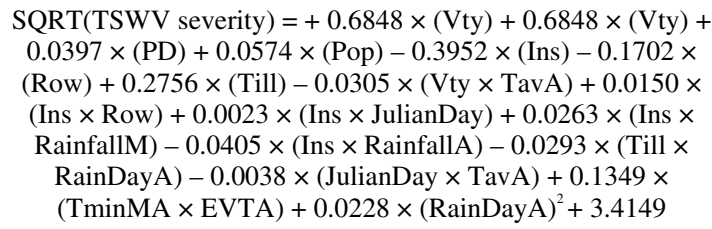

The values in equation 6 are the estimates of the regression coefficient and the intercept determined by stepwise regression. There were significant interactions between risk index components and the weather variables (Table 6) on the severity of spotted wilt. The index value for peanut variety (Vty) had a significant $(P<0.0001)$ interaction with the average daily temperature in April $(\operatorname{Tav} A)$. Similar interactions $(P<0.0001)$ were observed between the insecticide index value and the accumulated rainfall in March (RainfallM), and also with accumulated rainfall in April (RainfallA). A significant interaction $(P=0.0006)$ between the value for the tillage method (Till) and the number of rainy days in April (RainfallA) also contributed to the accuracy of the best model. The proportion of variance explained by the final model (equation 6) was approximately $61 \%$ (Fig. 3).

The best fitting model was evaluated using a frequency analysis of the exact match between the predicted and the actual observation. The model predicts low, moderate, and high. The number of an exact match between the predicted and the corresponding actual data was counted and recorded. The Bowker's test for symmetry $P$ values showed no significant disagreement between predicted and actual risk level for the 4 years. The model accuracy was 75.6, 63.3, 75.0, and 66.7\% in 1999, 2002, 2004, and 2005, respectively (Table 7).

\section{DISCUSSION}

TSWV is a major pathogen in the southeastern United States because of its impact on peanut and other crop production in this region. The virus has gained considerable attention since it was first detected in the southeast in 1986, and has consistently been observed in peanut fields across the southeast since then. In this study we examined the contribution of weather variables in predicting spotted wilt severity of peanut in Georgia, using survey data from four growing seasons with the goal of improving the current risk index accuracy in predicting the risk level of spotted wilt in peanut.

An improvement was observed by the inclusion of weather variables with a significant increase in $R^{2}$ value from 0.23 from 0.54 (Table 5). This could translate to better accuracy and could enhance the current risk index. Further analysis revealed that the average daily air temperature in April (TavA) had a significant impact in predicting the spotted wilt severity. Temperature effects on thrips and TSWV development have been documented in

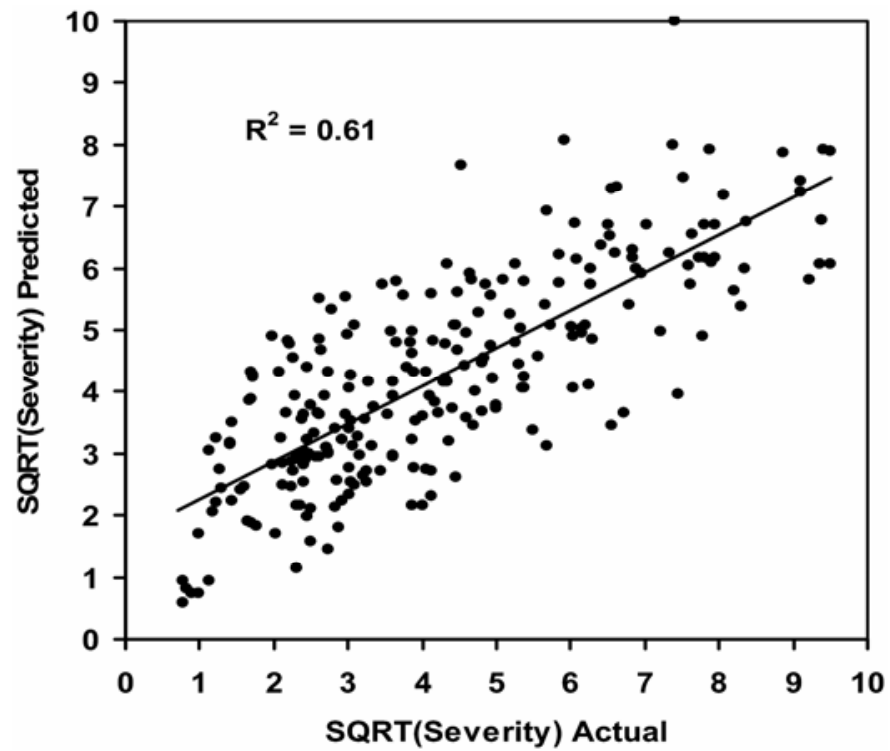

Fig. 3. Scatter plot of the actual and predicted values for the best fitting equation where SQRT (Tomato spotted wilt virus $[\mathrm{TSWV}$ ] severity) $=0.6848$ $\times($ Vty $)+0.0397 \times(\mathrm{PD})+0.0574 \times(\mathrm{Pop})-0.3952 \times($ Ins $)-0.1702 \times($ Row $)$ $+0.2756 \times($ Till $)-0.0305 \times($ Vty $\times$ TavA $)+0.0150 \times($ Ins $\times$ Row $)+0.0023 \times$ $($ Ins $\times$ JulianDay $)+0.0263 \times($ Ins $\times$ RainfallM $)-0.0405 \times($ Ins $\times$ RainfallA $)-$ $0.0293 \times($ Till $\times$ RainDayA $)-0.0038 \times($ JulianDay $\times$ TavA $)+0.1349 \times$ $($ TminMA $\times$ EVTA $)+0.0228 \times(\text { RainDayA })^{2}+3.4149$. The model accounted for $61 \%$ of the variation of spotted wilt severity.

TABLE 6. Analysis of variance table and the parameter estimates of interactions between risk index components and derived weather variables used in predicting SQRT (Tomato spotted wilt virus percent severity)

\begin{tabular}{|c|c|c|c|c|c|}
\hline Source & $\mathrm{df}$ & Sum of squares & Mean square & $F$ ratio & $\operatorname{Prob}(F)$ \\
\hline Regression & 15 & 692.90 & 46.19 & 23.73 & 0.00 \\
\hline Error & 227 & 441.87 & 1.95 & & \\
\hline Total & 242 & $1,134.79$ & & & \\
\hline Intercept & 3.4149 & 2.7790 & 1.2288 & 0.2204 & \\
\hline $\mathrm{X} 1$ & 0.6848 & 0.1269 & 5.3947 & 0.0000 & \\
\hline $\mathrm{X} 2$ & 0.0397 & 0.0139 & 2.8473 & 0.0048 & \\
\hline X5 & -0.1702 & 0.0592 & -2.8744 & 0.0044 & \\
\hline X6 & 0.2756 & 0.0690 & 3.9954 & 0.0001 & \\
\hline $\mathrm{X} 1 \times \mathrm{X} 8$ & -0.0305 & 0.0067 & -4.5485 & 0.0000 & \\
\hline $\mathrm{X} 4 \times \mathrm{X} 5$ & 0.0150 & 0.0045 & 3.3481 & 0.0010 & \\
\hline $\mathrm{X} 4 \times \mathrm{X} 7$ & 0.0023 & 0.0015 & 1.5580 & 0.1206 & \\
\hline $\mathrm{X} 4 \times \mathrm{X} 12$ & 0.0263 & 0.0044 & 5.9653 & $<0.0001$ & \\
\hline $\mathrm{X} 4 \times \mathrm{X} 14$ & -0.0405 & 0.0066 & -6.1296 & $<0.0001$ & \\
\hline
\end{tabular}

a X1-Vty, X2-PD, X3-Pop, X4-Ins, X5-Row, X6-Till, X7-JulianDay, X8-TavA, X10-TminMA, X12-RainfallM, X14-RainfallA, X15-RainDayA, and X17-EVTA. Parameter estimates explained $61 \%\left(R^{2}=0.61\right)$ of the variation in spotted wilt severity. 
several studies $(10,14,27,49)$. In the present study, a lower severity of spotted wilt was associated with a TavA between 19 and $22^{\circ} \mathrm{C}$, whereas higher severities were detected with higher and lower TavA. Chaisuekul and Riley (10), reported that the optimum temperature for oviposition of $F$. occidentalis and $F$. fusca was 24.5 and $24.9^{\circ} \mathrm{C}$, respectively. This indicates that higher TavA (22 to $23^{\circ} \mathrm{C}$ ) close to the optimum would favor increase in thrips populations. However, Chyzik and Ucko (14) suggested that the high temperature $\left(>40^{\circ} \mathrm{C}\right)$ and low humidity $(\approx 20 \%)$ during summer in Israel, caused a drastic reduction in $F$. occidentalis populations, despite the availability of flowering plant species (hosts) during the season. A significant correlation has been observed between degree day accumulation (using $13.3^{\circ} \mathrm{C}$ as base and $28.9^{\circ} \mathrm{C}$ as maximum) and the severity of TWSV on weeds at two Tifton locations, in Tift County (unpublished data). In general, temperature affects the life cycle of thrips and impacts the overall population of different thrips species, including viruliferous thrips which are part of overall population growth over time and space.

The rainfall variables (RainfallA, RainfallM, and RainDayA) could also be playing critical roles as indicated in the model. The accumulated rainfall in April (RainfallA $>6$ inch) was associated with higher spotted wilt severity. Harding (27) suggested that cool temperatures and/or rains were detrimental to the thrips colonization on onions in south Texas. In tobacco, heavy rains during the last week of March and cool temperatures in April resulted in no significant infection occurring until mid-May in 2005 (3). However, with increased temperatures, both the thrips populations and TSWV infection increased dramatically. Perhaps, host infection may be limited at or during rainfall events, but subsequent environmental conditions may be favorable for thrips development and subsequent TSWV infection (3).

The accumulated rainfall in April (RainfallA) had a significant interaction with the type of insecticide application at planting (Ins), whereas the tillage method employed in peanut cultivation (Till) had a significant interaction with the number of rain days in April (RainDayA) in relation to spotted wilt severity. Contributions by these variables might vary from optimum favorable temperature and moisture conditions for spotted wilt development on one hand, to extreme stress related conditions (e.g., high evapotranspiration) that could make the host plant more vulnerable to diseases and pests attack, on the other hand.

As the winter hosts senesce, viruliferous adult thrips migrate into susceptible emerging summer hosts/crops and subsequently spread TSWV. Studies have shown that the thrips population peak in the southeastern United States occurs from early May and early June (18-20,35,40,41). In North Carolina, the peak population of F. fusca, F. occidentalis, and Thrips tabaci in tobacco, tomato, and pepper occurred from mid-May through early June (19), while peak densities of $F$. fusca, $F$. occidentalis, and $F$. bispinosa (Morgan) on tobacco occurred from 3 to 24 May in Georgia (35). Groves et al. (21) found that the percentages of virus-transmitting adult vectors in agricultural fields tended to be highest during April in North Carolina. Although, a study by Wells et al. (49) indicated that peaks in the numbers of thrips and percentages of viruliferous thrips in the population may occur later than normal in a year with cool, wet, spring conditions as opposed to warm, dry, spring conditions, and could have significant implications on TSWV incidence in peanut and other crops.

Since weather variables appear to be one of the underlying factors in thrips population shift, the effect of average daily temperature in April (TavA) and the accumulated rainfall in April (RainfallA), on thrips population will fluctuate depending on field location and changing weather patterns form one year to the next. Therefore, a shift in thrips population peaks as a result of these factors could shift acceptable planting windows accordingly. Planting during the first 2 weeks of May typically results in the lowest incidence of spotted wilt, whereas planting in early April results in a greater incidence of the disease $(24,34,44)$. A planting date that prevents the synchronization of young peanut plants with the population peak of the thrips vector appears to significantly reduce the TSWV infection levels (4).

The age of the host plant is another important factor in peanut variety susceptibility to TSWV (4). Age-dependent resistance due to mature plant resistance has been documented in several studies on spotted wilt virus $(11,33,37,50)$. A study by Mandal et al. (32) on the transmission of TSWV in peanut by mechanical inoculation showed that the most susceptible growth stage of peanut to TSWV inoculation was 2 to 3 days after germination or approximately 6 to 7 days after planting. The soil temperature could also affect the rate and uniformity of seed germination and seedling emergence, as well as the subsequent plant population and individual plant vigor (15). The model presented showed a significant interaction between peanut variety (Vty) and the average daily temperature in April $(\operatorname{Tav} A)$. The interaction could reflect an indirect relationship between thrips population, thrips feeding preferences, and peanut variety. F. occidentalis and $F$. fusca are both important vectors of TSWV on peanut plants in Georgia and the southeastern United States.

A study by Camann et al. (9) on the spatial and temporal patterns of spotted wilt indicated that most TSWV infections arise from primary transmission with limited secondary spread after it becomes established in the field. The level of viruliferous thrips population pressure at the onset of the growing season that moves into the crop would appear to be critical in TSWV transmission. Other important factors include thrips feeding preferences, varietal responses to virus infection, host abundance, and host suitability. The spatiotemporal dynamics of thrips vector species

TABLE 7. Evaluation of the exact match between predicted risk and actual observations based on Bowker's test of symmetry in SAS using the three-category risk level (low, moderate, and high)

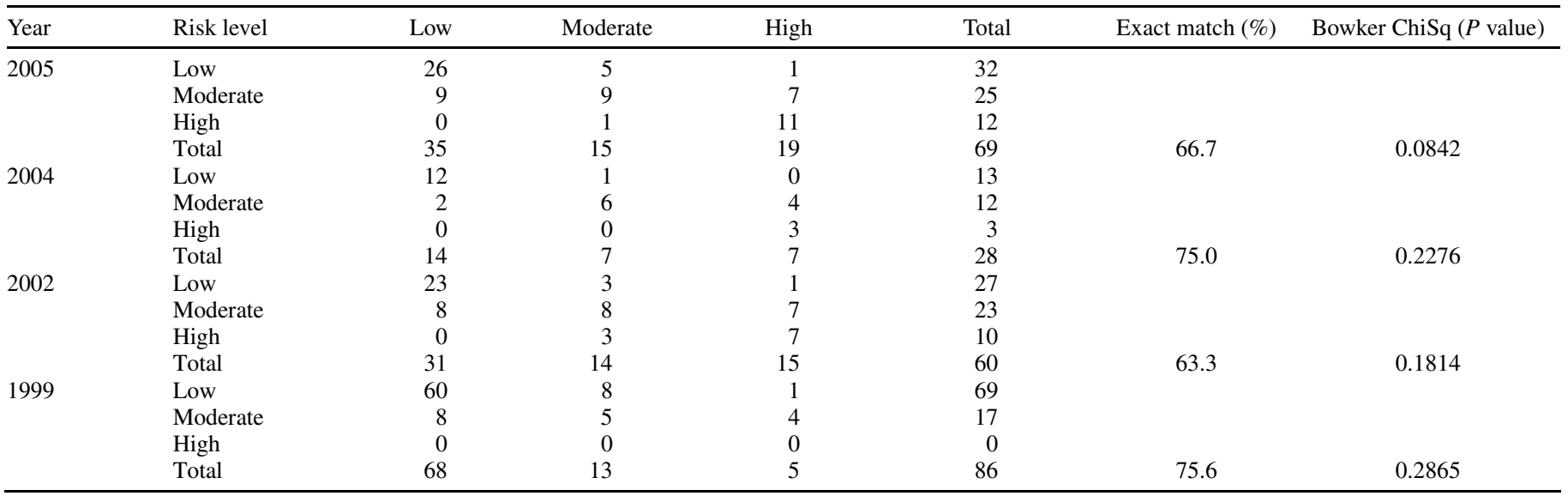


and their relative efficiency in transmitting TSWV into a peanut field in a given season would in part depend on preseason prevailing weather factors. In view of this, convergence of host suitability and vulnerability at an early developmental stage (May to June), with abundance of viruliferous thrips vector due to favorable weather condition prior to planting (March to April) would significantly increase risk of spotted wilt severity.

The current risk index has been effective in reducing spotted wilt severity, but with significant variation in accuracy from one year to the next. The influence of environmental factor (weather) is not currently accounted for in the risk index, as the components are mostly based on cultural practices. The result presented in this study showed the addition of weather variables, and their interactions with the current index components, improved the coefficient of determination $\left(R^{2}\right)$ by 0.38 or approximately $38 \%$ to a total of $61 \%$ of the identified variability. Although there remains substantial variability that is not accounted for, as previously mentioned, environmental factors during early spring have a strong influence on development of thrips and subsequent transmission of TSWV. Therefore, the addition of the weather variables may account for weather variation during the winter-spring period to better identify risk potential. The ultimate utility of the model will be based upon validation in the field.

Coupling a weather component with the risk index through the equation presented in this study would be an initial but significant step forward. This could assist peanut growers in the decisionmaking process for managing spotted wilt disease in the southeast. As we improve our understanding of the complex relationships, the weather parameters in the model could be simplified into points or values similar to the other components, for easy calculation of the risk level. The model presented in this study will be optimized further through an evaluation process. It would be valuable to evaluate this prediction model in years of low disease incidence and in other geographic areas where the disease epidemics occur, including Alabama and North Carolina.

\section{ACKNOWLEDGMENTS}

This work was conducted under the auspices of the Southeast Climate Consortium (SECC; http://secc.coaps.fsu.edu) and supported by a partnership with the U.S. Department of Agriculture-Risk Management Agency (USDA-RMA), by grants from the National Peanut Board/ Southeast Peanut Research Initiative, the U.S. National Oceanic and Atmospheric Administration-Climate Program Office (NOAA-CPO) and USDA Cooperative State Research, Education and Extension Services (USDA-CSREES), and by State and Federal funds allocated to Georgia Agricultural Experiment Stations Georgia Agricultural Experiment Stations Hatch project GEO01654. We thank the Spotted Wilt Eradication Action Team (SWEAT) for providing valuable survey data, inputs, and technical support.

\section{LITERATURE CITED}

1. Aramburu, J., Riudavets, J., Arnó, J., Laviña, A., and Moriones, E. 1997. The proportion of viruliferous individuals in field populations of Frankliniella occidentalis: Implications for tomato spotted wilt virus epidemics in tomato. Eur. J. Plant Pathol. 103:623-629.

2. Bertrand, P. F. 1997. 1996 Georgia Plant Disease Losses. Univ. Ga. Coop. Ext. Serv., Athens, GA

3. Brown, S., Csinos, A., Díaz-Pérez, J. C., Gitaitis, R., LaHue, S. S., Lewis, J., Martinez, N., McPherson, R., Mullis, S., Nischwitz, C., Riley, D., Sherwood, J., Sisson, V., Stephenson, M. G., and Wells, L. 2005. Tospoviruses in solanaceae and other crops in the coastal plain of Georgia. University of Georgia, College of Agriculture and Environmental Sciences, Research Report 704:19 (ISSN 0072-128X).

4. Brown, S. L., Culbreath, A. K., Todd, J. W., Gorbet, D. W., Baldwin, J. A., and Beasley, J. P. 2005. Development of a method of risk assessment to facilitate integrated management of spotted wilt of peanut. Plant Dis. 89:348-356.

5. Brown, S. L., Todd, J. W., and Culbreath, A. K. 1996. Effect of selected cultural practices on incidence of tomato spotted wilt virus and populations of thrips vectors in peanuts. Acta Hortic. 431:491-498.
6. Brown, S. L., Todd, J. W., Culbreath, A. K., Baldwin, J., Beasley, J., Kemerait, B., Prosko, E., Brenneman, T., Smith, N., Paz, J., Olatinwo, R., Tillman, B., Gorbet, D., Week, R., and Hagan, H. 2008. Minimizing disease of peanut in the southeastern United States. In: 2008 Peanut Update. University of Georgia, Cooperative Extension Service, College of Agriculture and Environmental Sciences CSS-08-0114:36-52.

7. Brown, S. L., Todd, J. W., Culbreath, A. K., Baldwin, J., Beasley, J., Kemerait, B., Prosko, Fletcher, S., Smith, N., Woodward, J., Gorbet, D., and Week, R. 2005. Minimizing disease of peanut in the southeastern United States. In: 2005 Peanut Update. University of Georgia, Cooperative Extension Service, College of Agriculture and Environmental Sciences CSS-05-0118:41-57.

8. Brown, S. L., Todd, J. W., Culbreath, A. K., Baldwin, J. A., Beasley, J. P., and Pappu, H. R. 1999. The tomato spotted wilt risk index-Identifying and avoiding high risk situations. Univ. Ga. Coop. Ext. Serv. Bull. 1165.

9. Camann, M. A., Culbreath, A. K., Pickering, J., Todd, J. W., and Demski, J. W. 1995. Spatial and temporal patterns of spotted wilt epidemics in peanut. Phytopathology 85:879-885.

10. Chaisuekul, C., and Riley, D. G. 2005. Host plant, temperature, and photoperiod effects on ovipositional preference of Frankliniella occidentalis and Frankliniella fusca (Thysanoptera: Thripidae). J. Econ. Entomol. 98:2107-2113.

11. Chaisuekul, C., Riley, D. G., and Pappu, H. 2003. Transmission of Tomato spotted wilt virus to tomato plants of different ages. J. Entomol. Sci. 38:126-135

12. Chamberlin, J. R., Todd, J. W., Beshear, R. J., Culbreath, A. K., and Demski, J. W. 1992. Overwintering hosts and wing form of thrips, Frankliniella spp., in Georgia (Thysanoptera: Thripidae): Implications for management of spotted wilt disease. Environ. Entomol. 21:121-128.

13. Chambers, W. S., and Sites, R. W. 1989. Overwintering thrips fauna in croplands of the Texas South Plains Southwest. Entomol. Exp. Appl. 14:325-328

14. Chyzik, R., and Ucko, O. 2002. Seasonal abundance of the western flower thrips Frankliniella occidentalis in the Arava Valley of Israel. Phytoparasitica 30:335-346.

15. Culbreath, A. K., Todd, J. W., and Brown, S. L. 2003. Epidemiology and management of tomato spotted wilt in peanut. Annu. Rev. Phytopathol. 41:54-75.

16. Culbreath, A. K., Todd, J. W., and Demski, J. W. 1992. Productivity of Florunner peanut infected with Tomato spotted wilt virus. Peanut Sci. 19:11-14.

17. Culbreath, A. K., Todd, J. W., Demski, J. W., and Chamberlin, J. R. 1992. Disease progress of spotted wilt in peanut cultivars Florunner and Southern Runner. Phytopathology 82:766-771.

18. DuRant, J. A., Roof, M. E., and Cole, C. L. 1994. Early season incidence of thrips (Thysanoptera) on wheat, cotton, and three wild host plant species in South Carolina. J. Agric. Entomol. 11:67-71.

19. Eckel, C. S., Cho, K., Walgenbach, J. F., Kennedy, G. G., and Moyer, J. W. 1996. Variation in thrips species composition in field crops and implications for tomato spotted wilt epidemiology in North Carolina. Entomol. Exp. Appl. 78:19-29.

20. Gitaitis, R. D., Dowler, C. C., and Chalfant, R. B. 1998. Epidemiology of tomato spotted wilt in pepper and tomato in southern Georgia. Plant Dis. 82:752-756.

21. Groves, R. L., Walgenbach, J. F., Moyer, J. W., and Kennedy, G. G. 2001. Overwintering of Frankliniella fusca (Thysanoptera: Thripidae) on winter annual weeds infected with Tomato spotted wilt virus and patterns of virus movement between susceptible weed hosts. Phytopathology 91:891-899.

22. Groves, R. L., Walgenbach, J. F., Moyer, J. W., and Kennedy, G. G. 2002. The role of weed hosts and tobacco thrips, Frankliniella fusca, in the epidemiology of Tomato spotted wilt virus. Plant Dis. 86:573-582.

23. Guam, W. G., Giliomee, J. H., and Pringle, K. L. 1994. Life history and life tables of the western flower thrips, Frankliniella occidentalis (Thysanoptera, Thripidae), on English cucumbers. B. Entomol. Res. 84:2219-2224

24. Hagan, A., and Week, R. 1998. Tomato Spotted Wilt Virus on Peanuts. Alabama Cooperative Extension System, Publication No. ANR-0574, Revised April 1998.

25. Hagan, A. K., Weeks, J. R., French, J. C., Gudauskas, R. T., Mullen, J. M., Gazaway, W. S., and Shelby, R. 1990. Tomato spotted wilt virus in peanut in Alabama. Plant Dis. 74:615.

26. Halliwell, R. S., and Philley, G. 1974. Spotted wilt of peanut in Texas. Plant Dis. Rep. 58:23-25.

27. Harding, J. A. 1961. Effect of migration, temperature, and precipitation on thrips infestations in south Texas. J. Econ. Entomol. 54:77-79.

28. Hoogenboom, G. 2000. The Georgia automated environmental monitoring network 2000. Pages 24-25 in: 24th Conf. on Agricultural and Forest Meteorology, American Meteorological Society, Boston.

29. Hoogenboom, G., Coker, D. D., Edenfield, J. M., Evans, D. M., and Fang, C. 2003. The Georgia Automated Environmental Monitoring Network: 10 
years of weather information for water resources management. Pages 896900 in: Proceedings of the 2003 Georgia Water Resources Conference. K. J. Hatcher, ed. The University of Georgia, Athens, GA.

30. Kemerait, R. C. 2006. Peanut. In: 2005 Georgia plant disease loss estimate, compiled by Alfredo Martinez. The University of Georgia, College of Agricultural and Environmental Sciences, Cooperative Extension Special Bulletin 41-08:11.

31. Lowry, V. K., Smith, J. W., Jr., and Mitchell, F. L. 1992. Life fertility tables for Frankliniella fusca and F. occidentalis on peanut. Ann. Entomol. Soc. Am. 85:744-754.

32. Mandal, B., Pappu, H. R., and Culbreath, A. K. 2001. Factors affecting mechanical transmission of Tomato spotted wilt virus to peanut (Arachis hypogaea). Plant Dis. 85:1259-1263.

33. Mandal, B., Wells, M. L., Martinez-Ochoa, N., Csinos, A. S., and Pappu, H. R. 2007. Symptom development and distribution of Tomato spotted wilt virus in flue-cured tobacco. Ann. Appl. Biol. 151:67-75.

34. McKeown, S. P., Todd, J. W., Culbreath, A. K., Gorbet, D. W., and Weeks, J. R. 2001. Planting date effects on tomato spotted wilt in resistant and susceptible peanut cultivars. (Abstr.) Phytopathology 91(suppl.):S60.

35. McPherson, R. M., Beshear, R. J., and Culbreath, A. K. 1992. Seasonal abundance of thrips (Thysanoptera: Suborders Terebrantia and Tubilifera) in Georgia flue-cured tobacco and impact of management on the incidence of tomato spotted wilt virus. J. Entomol. Sci. 27:257-268.

36. Mitchell, F. L., and Smith, J. W., Jr. 1991. Epidemiology of tomato spotted wilt virus relative to thrips populations. Virus-Thrips-Plant Interactions of Tomato Spotted Wilt Virus. Proceedings of a USDA Workshop. USDA-ARS Bull. ARS-87:46-52.

37. Moriones, E., Aramburu, J., Ruidavets, J., Arno, J., and Lavina, A. 1998. Effect of plant age at time of infection by Tomato spotted wilt virus on the yield of field-grown tomato. Eur. J. Plant Pathol. 104:295-300.

38. Pappu, H. R. 1997. Management of emerging virus threats of crops: Impact of biotechnology in controlling tospoviruses. Biotechnol. Dev. Monit. 31:14-17.

39. Rhainds, M., Cloutier, C., Shipp, L., Boudreault, S., Daigle, G., and Brodeur, J. 2007. Temperature-mediated relationship between western flower thrips (Thysanoptera:Thripidae) and chrysanthemum. Environ. Entomol. 36:475-483.
40. Riley, D. G., and Pappu, H. R. 2000. Evaluation of tactics for management of thrips-vectored Tomato spotted wilt virus in tomato. Plant Dis. 84:846-852.

41. Salguero Navas, V. E., Funderburk, J. E., Beshear, R. J., Olson, S. M., and Mack, T. P. 1991. Seasonal patterns of Frankliniella spp. (Thysanoptera:Thripidae) in tomato flowers. J. Econ. Entomol. 84:18181822.

42. SAS. 2003. SAS/STAT User's Guide. Release 9.1. SAS Institute Inc., Cary, NC.

43. Todd, J. W., Culbreath, A. K., and Brown, S. L. 1996. Dynamics of vector populations and progress of spotted wilt disease relative to insecticide use in peanuts. Acta Hortic. 431:483-490.

44. Todd, J. W., Culbreath, A. K., Brown, S. L., Gorbet, D. W., and Shokes, F. M. 1998. Development and validation of an integrated management system for spotted wilt disease in peanut. (Abstr.) Proc. Am. Peanut Res. Ed. Soc. 30:51.

45. Todd, J. W., Culbreath, A. K., Chamberlin, J. R., Beshear, R. J., and Mullinix, B. J. 1995. Colonization and population dynamics of thrips in peanuts in the southern United States. Pages 453-460 in: Thrips Biology and Management. B. L. Parker, M. Skinner, and T. Lewis, eds. Plenum Press, New York.

46. Van de Wetering, F., Goldbach, R., and Peters, D. 1996. Tomato spotted wilt tospovirus ingestion by first instar larvae of Frankliniella occidentalis is a prerequisite for transmission. Phytopathology 86:900-905.

47. Webb, S. E., Kok-Yohomi, M. L., and Tsai, J. H. 1997. Evaluation of Frankliniella bispinosa as a potential vector of tomato spotted wilt virus. (Abstr.) Phytopathology 87(suppl.):S102.

48. Welham, S. J., Turner, J. A., Gladders, P., Fitt, B. D. L., Evans, N., and Baierl, A. 2004. Predicting light leaf spot (Pyrenopeziza brassicae) risk on winter oilseed rape (Brassica napus) in England and Wales, using survey, weather and crop information. Plant Pathol. 53:713-724.

49. Wells, M. L., Culbreath, A. K., Todd, J. W., Csinos, A. S., Mandal, B., and McPherson, R. M. 2002. Dynamics of spring tobacco thrips (Thysanoptera:Thripidae) populations: Implications for Tomato spotted wilt virus management. Environ. Entomol. 31:1282-1290.

50. Wilson, C. R. 2001. Resistance to infection and translocation of Tomato spotted wilt virus in potatoes. Plant Pathol. 50:402-410. 